\title{
Comparison of the effects of pleurodesis induced by talc and hydrogen peroxide
}

\author{
Irfan Eser, Samil Gunay, Ibrahim Can Kurkcuoglu \\ Harran University Medical Faculty Department of Thoracic Surgery, Sanliurfa, Turkey
}

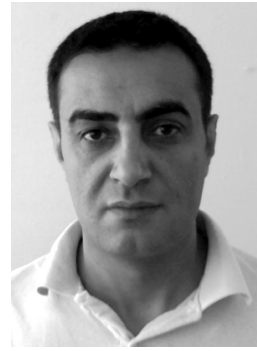

Kardiochirurgia i Torakochirurgia Polska 2013; 10 (3): 227-231

\begin{abstract}
Introduction: Pleural effusion occurs when fluid accumulates in the space between the parietal and visceral pleurae. It results either from increased production or decreased absorption of the fluid. It can arise from malignant or benign causes. The treatment for pleural effusions caused by malignant diseases is mainly palliative, with pleurodesis being the most frequently employed therapeutic method. The usage of chemical agents in pleurodesis causes inflammation which leads to adhesion of the pleural membranes.

The aim of the study was to analyze the inflammatory effect of hydrogen peroxide $\left(\mathrm{H}_{2} \mathrm{O}_{2}\right)$ as a pleurodesis agent.

Material and methods: The experimental study was conducted on 10 male New Zealand rabbits. In order to reduce the number of animals used in the experiment, both hemithoraces of the rabbits were used for pleurodesis. We divided the rabbits into two groups. In the first group, talc solution prepared in $0.9 \%$ saline was applied to the pleural cavities of both hemithoraces of 5 rabbits (a total of 10 pleural cavities), and, in the second group, a $3 \%$ hydrogen peroxide $\left(\mathrm{H}_{2} \mathrm{O}_{2}\right)$ solution prepared in $0.9 \%$ saline was applied to the pleural cavities of both hemithoraces of 5 rabbits (a total of 10 pleural cavities). Results: Blind macroscopic and microscopic examinations were carried out by a single pathologist using the scoring technique by Kaya et al. In macroscopic evaluation, grade 1 adhesion was found in the $\mathrm{H}_{2} \mathrm{O}_{2}$ group only. Grade 2 adhesion was achieved in 4 pleural cavities in the $\mathrm{H}_{2} \mathrm{O}_{2}$ group and 4 cases in the talc group. Grade 3 adhesion occurred in 3 cases in the $\mathrm{H}_{2} \mathrm{O}_{2}$ group and 6 cases in the talc group. In microscopic examination, grade 1 adhesion took place in the $\mathrm{H}_{2} \mathrm{O}_{2}$ group only. Grade 2 adhesion was achieved in 4 cases in the $\mathrm{H}_{2} \mathrm{O}_{2}$ group and 1 case in the talc group. Grade 3 adhesion was found to be similar in both groups. On the other hand, talc was found to be superior to hydrogen peroxide in terms of providing grade 4 adhesion.

Conclusions: It was determined that the use of talc in pleural cavities resulted in better grades of adhesion; however, $\mathrm{H}_{2} \mathrm{O}_{2}$ was found to diffuse more homogeneously. $\mathrm{H}_{2} \mathrm{O}_{2}$ is a chemical agent that has similar effects to talc in terms of pleurodesis,
\end{abstract}

\section{Streszczenie}

Wstęp: Wysięk opłucnowy ma miejsce wtedy, gdy w przestrzeni między opłucną ścienną a opłucną trzewną zgromadzi się płyn. Może to nastąpić zarówno w wyniku zwiększonej produkcji płynu, jak i jego zmniejszonej absorbcji. Przyczyny wysięku płucnego można podzielić na łagodne i złośliwe. Terapia wysięku płucnego spowodowanego chorobą złośliwą polega głównie na leczeniu paliatywnym oraz, w większości przypadków, zastosowaniu pleurodezy. Środki chemiczne używane w pleurodezie powodują stan zapalny, który prowadzi do adhezji błon opłucnej.

Celem pracy była analiza działania zapalnego nadtlenku wodoru $\left(\mathrm{H}_{2} \mathrm{O}_{2}\right)$ jako środka do pleurodezy.

Materiat i metody: Eksperyment przeprowadzono na 10 królikach nowozelandzkich płci męskiej. W celu zmniejszenia liczby zwierząt użytych w badaniu pleurodezę przeprowadzono na obu połowach tułowia królików. Zwierzęta podzielono na dwie grupy. W pierwszej grupie do każdej połowy klatki piersiowej 5 królików (w sumie 10 jam opłucnych) wprowadzono roztwór talku w 0,9-procentowej soli fizjologicznej. W drugiej grupie do każdej połowy klatki piersiowej 5 królików (w sumie 10 jam opłucnych) wprowadzono roztwór 3-procentowego nadtlenku wodoru $\left(\mathrm{H}_{2} \mathrm{O}_{2}\right)$ w 0,9-procentowej soli fizjologicznej.

Wyniki: Zaślepione badania makroskopowe i mikroskopowe zostały przeprowadzone przez jednego patologa przy użyciu metody punktacji proponowanej przez Kaya i wsp. W badaniu makroskopowym stopień 1 . adhezji wystąpił tylko w grupie $\mathrm{H}_{2} \mathrm{O}_{2}$. Stopień 2. adhezji uzyskano w 4 jamach opłucnych w grupie $\mathrm{H}_{2} \mathrm{O}_{2}$ i 5 w grupie talku. Stopień 3. adhezji stwierdzono w 3 przypadkach w grupie $\mathrm{H}_{2} \mathrm{O}_{2}$ i 6 w grupie talku. W badaniu mikroskopowym stopień 1 . adhezji wystąpił tylko w grupie $\mathrm{H}_{2} \mathrm{O}_{2}$. Stopień 2 adhezji uzyskano w 4 przypadkach w grupie $\mathrm{H}_{2} \mathrm{O}_{2}$ i w 1 przypadku w grupie talku. Stopień 3 adhezji był podobny w obu grupach. Jeżeli jednak chodzi o zapewnianie adhezji stopnia 4., talk okazał się skuteczniejszy niż $\mathrm{H}_{2} \mathrm{O}_{2}$.

Wyniki: Ustalono, że wprowadzenie talku do jamy opłucnej zapewniało wyższy stopień adhezji, jednak $\mathrm{H}_{2} \mathrm{O}_{2}$ rozprowadzał się bardziej równomiernie. $\mathrm{H}_{2} \mathrm{O}_{2}$ to środek chemiczny o podobnym działaniu do talku przy zastosowaniu w pleurodezie,

Address for correspondence: Irfan Eser, Harran University Medical Faculty, Yenisehir Campus, 63100 Sanliurfa, Turkey, phone: +90 53268627 15, e-mail: drirfanes@gmail.com 
but demonstrates better diffusion on the pleural surfaces. It is also inexpensive, accessible, and easy to administer.

Key words: hydrogen peroxide, talc pleurodesis, pleural effusion.

\section{Introduction}

Pleural effusion occurs when fluid accumulates in the space between the parietal and visceral pleurae. It results either from increased production or decreased absorption of the fluid. The most common causes of benign pleural effusion are congestive heart failure, tuberculosis, and pneumonia. When it comes to malignant pleural effusion, it is caused mainly by lung cancer; other causes include breast cancer, lymphoma, ovary cancer, and malignancies of the gastrointestinal system [1, 2]. Lung and breast cancers account for approximately $75 \%$ of malignant pleural effusions [3, 4].

Pleurodesis performed by an intrapleural injection of a sclerosing agent, administered after the evacuation of the pleural fluid, is the most common method used in the palliative treatment of malignant pleural effusions [5]. In order for pleurodesis to be successful, it is necessary for mesothelial cells to produce and release inflammatory and fibrotic mediators. The inflammation is initiated when a chemical sclerosing agent is injected into the pleural cavity. The administration of the substance and the following chemical reaction result in intense inflammation, which causes the pleurae to adhere to each other [6, 7]. Many sclerosing agents have been used in the treatment of malignant pleural effusion.

Talc, bleomycin, tetracycline, doxycycline, interferons, interleukins, radioactive isotopes $\left(\mathrm{Au}, \mathrm{CrPO}_{4}\right)$, various chemotherapeutic agents (cisplatin, etoposide, cytarabine, fluorouracil, mitomycin-c, cyclophosphamide, doxorubicin) are commonly used for pleurodesis. Most of these agents may cause serious side effects or fail to provide the desired outcome. Furthermore, they are expensive and hard to administer. Currently, the most commonly used pleurodesis agent is talc. However, it has been reported that this agent is burdened with many systemic side effects, ranging from acute respiratory distress syndrome (ARDS) to embolization $[8,9] . \mathrm{H}_{2} \mathrm{O}_{2}$ is inherently used by the leukocytes in their bactericidal activity. Moreover, it is employed as a disinfectant and enhances inflammation. Since the main factor starting pleurodesis is inflammation, our aim was to demonstrate the pleurodesis efficacy of $\mathrm{H}_{2} \mathrm{O}_{2}$ as an alternative to talc. For this reason, talc and $\mathrm{H}_{2} \mathrm{O}_{2}$ were compared through animal experiments.

\section{Material and methods}

This study was approved prospectively by the Ethics Committee of the Faculty of Medicine at Pamukkale University (decision of 11.12.2007/72). It was conducted on 10 male New Zealand white rabbits. The weight of the rabbits ranged from 2.0 to $2.5 \mathrm{~kg}$. In order to reduce the num- zapewniający jednak bardziej równomierne rozprowadzenie po powierzchni opłucnej. Jest on również tani oraz łatwy do uzyskania i zastosowania.

Słowa kluczowe: nadtlenek wodoru, pleurodeza talkiem, wysięk opłucnowy.

ber of animals used in the study, both hemithoraces of the rabbits were used for pleurodesis. The animals were divided into groups. In the first group, talc solution prepared in $0.9 \%$ saline was applied to the pleural cavities of both hemithoraces of 5 rabbits (a total of 10 pleural cavities), and, in the second group, a $3 \%$ hydrogen peroxide $\left(\mathrm{H}_{2} \mathrm{O}_{2}\right)$ solution prepared in $0.9 \%$ saline was applied to the pleural cavities of both hemithoraces of 5 rabbits (a total of 10 pleural cavities). STERITALC ${ }^{\circledR}$ (large particle size talc for internal use produced by Novatech) was used in the study. Before the surgical procedure, light anesthesia was administered to all the rabbits by intramuscular injection of $35 \mathrm{mg} / \mathrm{kg}$ ketamine hydrochloride and $5 \mathrm{mg} / \mathrm{kg}$ xylazine hydrochloride. Following the anesthesia, both hemithoraces of the rabbits were shaved and sterilized with Batticon.

After antisepsis, a $2 \mathrm{~cm}$ incision was performed in the middle of the area between the vertebrae and the sternum. The $8^{\text {th }}$ intercostal space was then exposed through dissection, providing access to the parietal pleura. Next, a 25 gauge needle was placed in the pleural cavity. The occurring artificial pneumothorax was drained by a threeway tap.

Preparation of talc: $400 \mathrm{mg} / \mathrm{kg}$ asbestos-free talc $(\mathrm{pH}=8.4)$ was dissolved in $20 \mathrm{cc}$ of $0.9 \%$ saline in order to be administered to the pleural cavities of the rabbits from the first group.

Preparation of hydrogen peroxide: $5 \mathrm{CC}$ of $\mathrm{H}_{2} \mathrm{O}_{2}$ was dissolved in 20 cc of $0.9 \%$ saline in order to be administered to the pleural cavities of the rabbits from the second group.

Depending on the group, $5 \mathrm{cc}$ of talc or $\mathrm{H}_{2} \mathrm{O}_{2}$ was injected through catheters placed in the right and left pleural cavities of the rabbits. After the injection of the sclerosing agent, the occurring artificial pneumothorax was drained with a $50 \mathrm{ml}$ injector. Thereafter, muscles and skin were sutured with $3 / 0$ catgut and 3/0 silk. The rabbits were closely monitored in terms of diet, tachypnea, agitation, and pain within the first 24 hours following the surgery.

After the operation, an intramuscular antibiotic (250 mg cefazolin sodium) injection was considered to be the only treatment option required with respect to infection risk.

All rabbits were put down after one month by the administration of a lethal dose of pentobarbital. En bloc resection was performed on both hemithoraces of the rabbits. To prevent lung collapse and ensure internal fixation, 10\% neutral buffered formalin was injected through the trachea in an amount sufficient to fill up the trachea and bronchi. The tracheal cavity was stitched with silk sutures. The specimens were then kept in 10\% neutral buffered formalin for 96 hours and, subsequently, analyzed pathologically.

Blind macroscopic and microscopic examinations were performed by a single pathologist using the scoring tech- 
nique by Kaya et al. [10]. Macroscopic and microscopic scores and grades are presented in Tables I and II.

Vertical incisions were performed through the midclavicular line on each hemithorax to evaluate macroscopic pleural changes. The pleural cavity was analyzed macroscopically to observe adhesion formation after the ribs and sternum were removed. Some tissue sections were excised from the lung to expose the largest possible visceral pleural surface; these sections were then analyzed microscopically. The following microscopic changes in the lung were observed and analyzed: alveolar collapse (changes in alveolar sacs, canals, and septum; decrease in gas exchange spaces), alveolar hemorrhage (blood flow to alveolar spaces and base), edema (accumulation of protein and amorphous material within the alveolar space), changes in the visceral pleura, and cellular infiltration (number of cells in alveoli). All changes were scored with the help of histopathological examination in order to obtain semi-quantitative parameters.

\section{Statistical analysis}

All data are presented as mean \pm standard deviation; average histopathological scores obtained in the two different treatment groups were compared using the unpaired $t$ test. Statistical analysis was carried out using the Statistical Package for the Social Sciences (SPSS - version 10.0) software for Windows. $P<0.05$ values were regarded as statistically significant.

\section{Results}

Talc was administered to 5 rabbits from the first group, and $\mathrm{H}_{2} \mathrm{O}_{2}$ was administered to 5 rabbits from the second group, separately into each hemithorax. The rabbits did not develop respiratory distress after the administration of talc or $\mathrm{H}_{2} \mathrm{O}_{2}$.

Tab. I. Macroscopic score

\begin{tabular}{ll} 
Macroscopic score & Results of macroscopic examination \\
\hline 0 & normal \\
\hline 1 & less than three adhesions \\
\hline 3 & more than three adhesions \\
\hline 4 & massive adhesion \\
\hline
\end{tabular}

Tab. II. Microscopic score

\begin{tabular}{ll} 
Microscopic score & Results of microscopic examination \\
0 & none \\
\hline 1 & very little \\
\hline 2 & mild \\
\hline 3 & intermediate \\
\hline 4 & severe \\
\hline
\end{tabular}

All rabbits promptly returned to their normal diet and behavior. None of the experimental animals developed ARDS, pneumothorax, wound site infection, hemorrhage, or other similar complications. All rabbits were put down after one month. Blind macroscopic and microscopic examinations were carried out by a single pathologist using the scoring technique by Kaya et al. [10]. The macroscopic results were statistically evaluated with the Mann-Whitney $U$ test, utilizing the SPSS software. In macroscopic evaluation, grade 1 adhesion was only found in 3 cases in the $\mathrm{H}_{2} \mathrm{O}_{2}$ group. Grade 2 adhesion was achieved in 4 pleural cavities in the $\mathrm{H}_{2} \mathrm{O}_{2}$ group and 4 cases in the talc group. Grade 3 adhesion occurred in 3 cases in the $\mathrm{H}_{2} \mathrm{O}_{2}$ group and 6 cases in the talc group. Grade 0 and grade 4 adhesion was not observed macroscopically in either of the groups. The microscopic results were statistically evaluated with the MannWhitney $U$ test, using the SPSS software. There were no rabbits exhibiting grade 0 adhesion in either of the groups (Table III). Grade 1 adhesion occurred in only 2 cases in the $\mathrm{H}_{2} \mathrm{O}_{2}$ group; in the talc group, none of the pleural cavities were classified as having grade 1 adhesion. Grade 2 adhesion was achieved in 4 cases in the $\mathrm{H}_{2} \mathrm{O}_{2}$ group and 1 case in the talc group. In the $\mathrm{H}_{2} \mathrm{O}_{2}$ group, 3 pleural cavities displayed grade 3 adhesion; in the talc group, the outcome

Tab. III. Macroscopic evaluation

\begin{tabular}{lcc} 
Macroscopic evaluation & $\mathrm{H}_{2} \mathrm{O}_{2}$ & Talc \\
Grade 0 & 0 & 0 \\
\hline Grade 1 & 3 & 0 \\
\hline Grade 2 & 4 & 4 \\
\hline Grade 3 & 3 & 6 \\
\hline Grade 4 & 0 & 0 \\
\hline Total & 10 & 10 \\
\hline
\end{tabular}

Tab. IV. Microscopic evaluation

\begin{tabular}{lcc} 
Microscopic evaluation & $\mathrm{H}_{2} \mathrm{O}_{2}$ & Talc \\
\hline Grade 0 & 0 & 0 \\
\hline Grade 1 & 2 & 0 \\
\hline Grade 2 & 4 & 1 \\
\hline Grade 3 & 3 & 3 \\
\hline Grade4 & 1 & 6 \\
\hline Total & 10 & 10 \\
\hline
\end{tabular}

Tab. V. Statistical analysis

\begin{tabular}{lccc} 
Statistical analysis & $\mathrm{H}_{2} \mathrm{O}_{2}$ & Talc & $p$ Values \\
Macroscopic group & $2.00 \pm 0.82$ & $2.60 \pm 0.52$ & 0.084 \\
\hline Microscopic group & $2.30 \pm 0.95$ & $3.50 \pm 0.71$ & 0.008 \\
\hline
\end{tabular}


was the same. Grade 4 adhesion was found in only 1 pleural cavity in the $\mathrm{H}_{2} \mathrm{O}_{2}$ group and as many as 6 pleural cavities in the talc group (Table IV). Based on the statistical evaluation of the macroscopic and microscopic data, the $p$ value was found to be 0.084 for the macroscopic data; no difference between the groups was detected. Since the $p$ value for the microscopic data was found to be 0.008 , the results from the talc group were revealed to be superior to the other group $(p<0.05)$ (Table $\mathrm{V})$.

\section{Discussion}

Pleural effusion is abnormal fluid accumulation in the space between the visceral and parietal pleurae, which results from the disturbance of the balance between the production and absorption of pleural fluid. The underlying cause must be removed to ensure successful treatment. Pleural effusion can be of malignant or benign origin. If it is not possible to treat the underlying cause, the therapy involves the evacuation of the pleural fluid and the initiation of pleurodesis. Pleurodesis is the adhesion of the parietal and visceral pleurae to each other, induced by a surgical method or a chemical agent. In the case of massive and recurrent pleural effusions, various chemical sclerosing agents, especially sterile talc, are used after the evacuation of the pleural fluid; this method is less invasive than thoracotomy.

The agent used for pleurodesis should be characterized by high efficacy, ease of access and administration, low price, and as few side effects as possible. Talc's mechanism of action consists in the granulomatous inflammation developed in association with the foreign body effect caused by talc particles. No granulomatous pleural reaction was observed during the pathological examination of the animals injected with hydrogen peroxide. For this reason, we infer that the mechanism of action of hydrogen peroxide is not associated with a foreign body reaction. Hydrogen peroxide catalyzed by myeloperoxidase generates hypochlorous acid $(\mathrm{HOCl})$, increases the bactericidal activity of leukocytes through its cytotoxic action, and causes inflammation by triggering intracellular apoptosis [11].

Talc is available in the form of spray or suspension. Talc spray is used in thoracoscopy, while talc suspension is used during tube thoracostomy.

A clinical study comparing these two forms of talc, conducted by Francisco et al., showed that using talc spray in thoracoscopy is the more effective method [12]. The reason is that talc spray is evenly distributed on the lung surface as a thin layer. In turn, talc suspension generally accumulates in the lower regions and is not distributed evenly on the surface. Since $\mathrm{H}_{2} \mathrm{O}_{2}$ is a liquid, it is evenly distributed on the pleural surface, and, therefore, it is superior to the talc suspension. However, the fact that the talc spray is only applicable during thoracoscopy poses a risk of additional surgery and anesthesia for the patient. If thoracoscopy is not required for any other reason, such as diagnostic purposes, we are of the opinion that it should be avoided in the administration of talc.

PET-CT, used to diagnose, follow, and stage cancer, is a technique based on the glucose consumption of cells. This method facilitates the detection of cancerous cells, but it can present false positives in the presence of inflammatory and granulomatous diseases [13]. The false positive associated with talcoma, a side effect of talc use, was described in the literature. Ahmad Zadehfar et al. detected pleural involvement during a PET-CT scan of a patient exposed to talc pleurodesis due to pneumothorax. They associated it with inflammation caused by talc [13]. Montes et al. observed extreme extrapleural talc accumulation due to the foreign body effect of talc caused by pleurodesis with a high talc dose. They reported that pleurodesis with a high talc dose should be avoided [15]. Based on these findings, we believe that PET-CT used to follow up patients suffering from malignant pleural effusion could lead to false positive results. Furthermore, $\mathrm{H}_{2} \mathrm{O}_{2}$ does not cause accumulation in pleurodesis and ensures diffuse distribution, both macroscopically and microscopically.

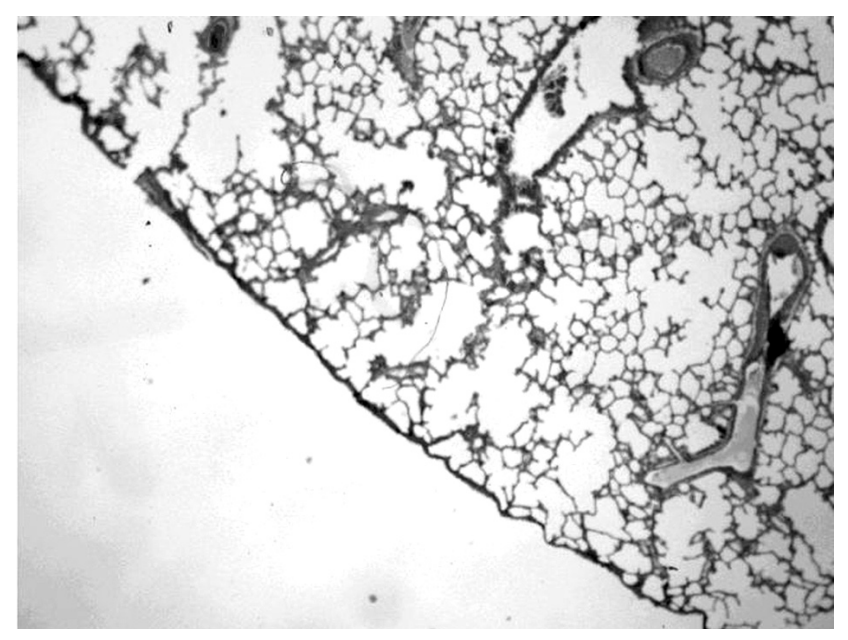

Fig. 2. $\mathrm{H}_{2} \mathrm{O}_{2}$ group - grade 2 pleural adhesion with $\times 10$ Masson's trichrome stain 
Viallat et al. reported a success rate of $90 \%$ for patients with malignant pleural effusion treated with thoracoscopic talc pleurodesis. The following complications were found in the said study: fever (9.8\%), empyema (2.5\%), and pneumonia (0.8\%) [16]. Lange et al. reported that talc pleurodesis led to a moderate restriction of the total lung capacity to $89 \%$ of what was expected with respect to the series of pneumothorax cases followed up for a period of 22-35 years [17].

What is more, it is known that talc causes severe side effects, such as ARDS. Due to this reason, many research projects and studies have been and are still being conducted all around the world to find other agents for pleurodesis. Vargas et al. observed that intrapleural injection of bleomycin in the amount of $1.5-3 \mathrm{mg} / \mathrm{kg}$ did not cause any significant inflammation or fibrosis in 11 out of 12 rabbits. They detected limited inflammation in only one rabbit [18]. Another study of Vargas et al., conducted to compare the effects of pleurodesis initiated by Corynebacterium parvum and tetracycline in rabbits, showed that 4 and $8 \mathrm{mg}$ of Corynebacterium parvum did not cause any fibrogenic effects [19]. In our study, we achieved a powerful and successful outcome with the use of $\mathrm{H}_{2} \mathrm{O}_{2}$, similar to that achieved through talc pleurodesis.

\section{Conclusions}

Experiments conducted on rabbits have demonstrated that talc ensures better adhesion; however, $\mathrm{H}_{2} \mathrm{O}_{2}$ provided more diffuse distribution. $\mathrm{H}_{2} \mathrm{O}_{2}$ is characterized by ease of access and administration, low cost, diffuse distribution on the pleural surfaces, and a strong effect, similar to that of talc pleurodesis. The conducted research suggests that $\mathrm{H}_{2} \mathrm{O}_{2}$ is an efficient chemical pleurodesis agent.

\section{References}

1. Loddenkemper R. Management of malignant pleural effusion. Pneumologic 2005; 2: 120-135.

2. Zakman G, Lechapt E, Bergot E. Management of malignant pleural effusion. Rev Prat 2007; 57: 513-523.

3. Lynch TJ. Management of malignant pleural effusions. Chest 1993; 103: 385S-389S
4. Webb WR, Ozmen V, Moulder PV, Shabahang B, Breaux J. lodized talc pleurodesis for the treatment of pleural effusions. J Thorac Cardiovasc Surg 1992; 103: 881-886.

5. Patz EF. Malignant pleural effusions. Chest 1998; 113: 74S-77S.

6. Panadero FR, Antony VB. Pleurodesis: state of the art. Eur Respir J 1997; 10: 1648-1654.

7. Agrenius V, Chmielewska J, Widström O, Blombäck M. Pleural fibrinolytic activity is decreased in inflammation as demonstrated in quinacrine pleurodesis treatment of malignant pleural effusion. Am Rev Respir Dis 1989; 140: 1381-1385.

8. Rinaldo JE, Owens GR, Rogers RM. Adult respiratory distress syndrome following intrapleural instillation of talc. J Thorac Cardiovasc Surg 1983; 85: 523-526.

9. Campos JR, Werebe EC, Vargas FS, Jatene FB, Light RW. Respiratory failure due to insufflated talc. Lancet 1997; 349: 251-252.

10. Ors Kaya S, Bir F, Atalay H, Onem G, Aytekin FO, Saçar M. Effect of diclofenac on experimental pleurodesis induced by tetracycline in rabbits. J Investig Med 2005; 53: 267-270.

11. Haji MP. Antioxidant therapy in the critically ill. British Journal of Intensive Care 2000; 10: 88-92.

12. Vargas FS, Teixeira LR, Antonangelo L, Vaz MA, Carmo AO, Marchi E, Light RW. Experimental pleurodesis in rabbits induced by silver nitrate or talc: 1-year follow-up. Chest 2001; 119: 1516-1520.

13. Narayanaswamy S, Kamatha S, Williams M. UK CT appearances of talc pleurodesis. Clin Radiol 2007; 6: 233-237.

14. Ahmadzadehfar H, Palmedo H, Strunk H, Biersack HJ, Habibi E, Ezziddin S. False positive 18F-FDG-PET/CT in a patient after talc pleurodesis. Lung Cancer 2007; 58: 418-421.

15. Montes JF, Ferrer J, Villarino MA, Baeza B, Crespo M, Garcia-Valero J. Influence of talc dose on extrapleural talc dissemination after talc pleurodesis. Am J Respir Crit Care Med 2003; 168: 348-355.

16. Viallat JR, Rey F, Astoul P, Bautin C. Thoracoscopic talc poudrage pleurodesis for malignant effusions: a review of 360 cases. Chest 1996; 110: 1387-1393.

17. Lange P, Mortensen J, Groth S. Lung function 22-35 years after treatment of idiopathic spontaneous pneumothorax with talc poudrage or simple drainage. Thorax 1988; 43: 559-561.

18. Vargas FS, Wang NS, Lee HM, Gruer SE, Sassoon CS, Light RW. Effectiveness of bleomycin in comparison to tetracycline as pleural sclerosing agent in rabbits. Chest 1993; 104: 1582-1584.

19. Vargas FS, Wang NS, Teixeira LR, Carmo AO, Silva LM, Light RW. Corynebacterium parvum versus tetracycline as pleural sclerosing agents in rabbits. Eur Respir J 1995; 8: 2174-2177. 